\title{
Continuous reproduction of Sinanodonta woodiana (Lea, 1824) females: an invasive mussel species in a female-biased population
}

\author{
Anna Maria Labecka $\cdot$ Jozef Domagala
}

Received: 8 January 2016/Revised: 21 March 2016/Accepted: 14 May 2016/Published online: 7 June 2016

(C) The Author(s) 2016. This article is published with open access at Springerlink.com

\begin{abstract}
The reproductive activity of females of the Chinese pond mussel (Sinanodonta woodiana) was investigated in a European population inhabiting cooling water. The study used histological and stereological methods to determine gonad structure, changes in reproductive follicles during gametogenesis, oocyte development, glochidia structure, and brooding periods. Water in the channel of the "Dolna Odra" power plant did not freeze during the winter, and its mean annual temperature was $18.4^{\circ} \mathrm{C}$. The population sex ratio was female biased $\left(\chi^{2}=25.70\right.$, $\mathrm{df}=1, P<0.0001)$. Ovaries in mussels were formed by reproductive follicles. Previtellogenic and vitellogenic oocytes were attached to the follicle wall via the cytoplasmic stalk, and mature ovulated oocytes were present in the follicle lumen. Individuals with mature oocytes in gonads were present over the whole two-year study period, which indicates the continuous activity of gonads. Hooked glochidia had
\end{abstract}

Guest editors: Manuel P. M. Lopes-Lima, Ronaldo G. Sousa, Lyuba E. Burlakova, Alexander Y. Karatayev \& Knut Mehler / Ecology and Conservation of Freshwater Bivalves

Present Address:

A. M. Labecka ( $\square)$

Institute of Environmental Sciences, Jagiellonian University, Gronostajowa 7, 30-387 Kraków, Poland

e-mail: anna.labecka@uj.edu.pl

A. M. Labecka · J. Domagala

Department of General Zoology, University of Szczecin,

Felczaka 3c, 71-412 Szczecin, Poland a larval thread. Females incubated the offspring in gill marsupia of outer demibranchs and were characterized by multiple tachytictic brooding periods. All gravid individuals presented mature and spent stages of gonadal development. The study provides the first direct information about the reproductive dynamics of this invasive species outside its original Asiatic range.

Keywords Brooding periods - Glochidia . Gonadal development stages · Oogenesis . Power plant $\cdot$ Reproduction $\cdot$ Sex ratio

\section{Introduction}

In the Unionoidea, finding a host fish is a crucial event in the life cycle of parasitic glochidia, which may facilitate larvae migration and the colonization of new areas. Glochidia attached to the fish body migrate to certain distances, undergo metamorphosis, and begin a relatively sedentary lifestyle in a new habitat (Kat, 1984; Rogers-Lowery \& Dimock, Rogers-Lowery et al., 2006). Most unionid species are also generalists with respect to the choice of host, including cases of encystation on the body of fish species with which they do not coexist in the areas of their natural range of distribution (Barnhart et al., 2008; Łabęcka, 2009; Douda et al., 2012). In addition to the natural tendency of organisms for expansion, many spectacular examples of extension in the 
distribution range of different aquatic species have been observed in connection with the development of the transport and construction of channels linking river and marine catchment basins (Hebert et al., 1989). Human activity contributes to the formation of new habitats, often with increased temperature, like discharge channels of cooling water, greenhouses, or botanical gardens. These sites can be inhabited by species arriving even from distant climate zones (Alexandrowicz, 1993; Piechocki et al., 2003; Strzelec et al., 2006), and an increase in the size of the invaders' population can be facilitated, for example, by hermaphroditic reproduction and/or breeding multiple times per year (Łabęcka, 2009). Allendorf $\&$ Lundquist (2003) argue that some species may be intrinsically better competitors because they evolved in a more competitive environment. Jokela \& Lively (1995), Lively \& Dybdahl (2000), and Sousa et al. (2005) also argue that the absence of natural enemies provides non-indigenous species with more resources available for growth and reproduction, and thereby allows them to out-compete native species.

The Chinese pond mussel Sinanodonta woodiana is indigenous to Asia and arrived in Europe as a result of human activity. It appeared for the first time in the early 1960s in Romania and Hungary, and was found in breeding ponds to which herbivorous cyprinid fry (grass carp Ctenopharyngodon idella and silver carp Hypophthalmichthys molitrix) infected with glochidia were brought from the native regions of this mussel, i.e. from the Amur and Yangtze Rivers (Petró, 1984; Sárkány-Kiss, 1986). In Poland, this species first appeared in the early 1980s in the Heated Konin Lakes system (the Kuyavian Lake District, central Poland), to where it was brought with $H$. molitrix and bighead carp H. nobilis imported from Hungary (Zdanowski, 1996; Soroka et al., 2014). In 2003, live adult individuals were found in the "Dolna Odra" power plant's cooling water (Western Pomerania Region, north-west Poland) (Domagała et al., 2003). The channel in which the species was detected is heated and filled with water used for cooling power generators. This water is discharged from the power plant by a separate $3.6 \mathrm{~km}$ channel to the Eastern Odra River.

Interest in the biological problems associated with cooling water as a habitat for organisms has been growing since heat and power plants implemented cooling systems for power generators supplied with water from nearby watercourses (Silayeva \& Protasov, 2002; Domagala et al., 2014; Pilecka-Rapacz et al., 2015). Cooling water increases the temperature of the water in a reservoir receiving water from the power plant and modifies the reproductive activity of cold-blooded animals (Domagała et al., 2015; Kirczuk et al., 2015). In unionids, water temperature influences the incubation time of glochidia in gill demibranchs (short-tachytictic brooding, long-bradytictic brooding), the time of their release (summer and winter releasing), overwintering site (parent and/or host overwintering), and the number of clutches per year (Heard, 1998; Graf \& Ó Foighil, 2000; Watters \& O'Dee, 2000).

Because of the rapid spread of $S$. woodiana in European waters (Giradi \& Ledoux, 1989; Košel, 1995; Beran, 1997; Domagała et al., 2003; Paunovic et al., 2006; Munjiu \& Shubernetski, 2008; Cappelletti et al., 2009; Pou-Rovira et al., 2009; Lajtner \& Crnčan, 2011), we undertook a study to investigate female reproductive activity using histological and stereological methods. For this purpose we analysed (i) changes in the morphology of reproductive follicles and (ii) oocytes during gametogenesis. We described (iii) the structure of glochidia and identified (iv) brooding periods in the female gills. The study was carried out on Chinese pond mussel females living in the cooling water of the "Dolna Odra" power plant's Ciepły Channel. This habitat is connected with the Eastern Odra River and is the largest source of larvae of this species, which colonize further sections of the Odra River (Domagała et al., 2007).

\section{Materials and methods}

Field methods

Sinanodonta woodiana was captured by free diving and on the shallow level, once a month between July 2004 and June 2006 (with the exception of October 2005). Individuals were collected by hand, at depths of 0.5-2.5 m, at about $300 \mathrm{~m}$ distance from the power plant $\left(\mathrm{N} 53^{\circ} 12^{\prime} \mathrm{E} 14^{\circ} 28^{\prime}\right.$; Fig. 1). The collected bivalves were transported to the laboratory and placed in aerated aquaria where the water temperature was the same as in the sampling sites. Live bivalves were kept in aquaria for several hours and 


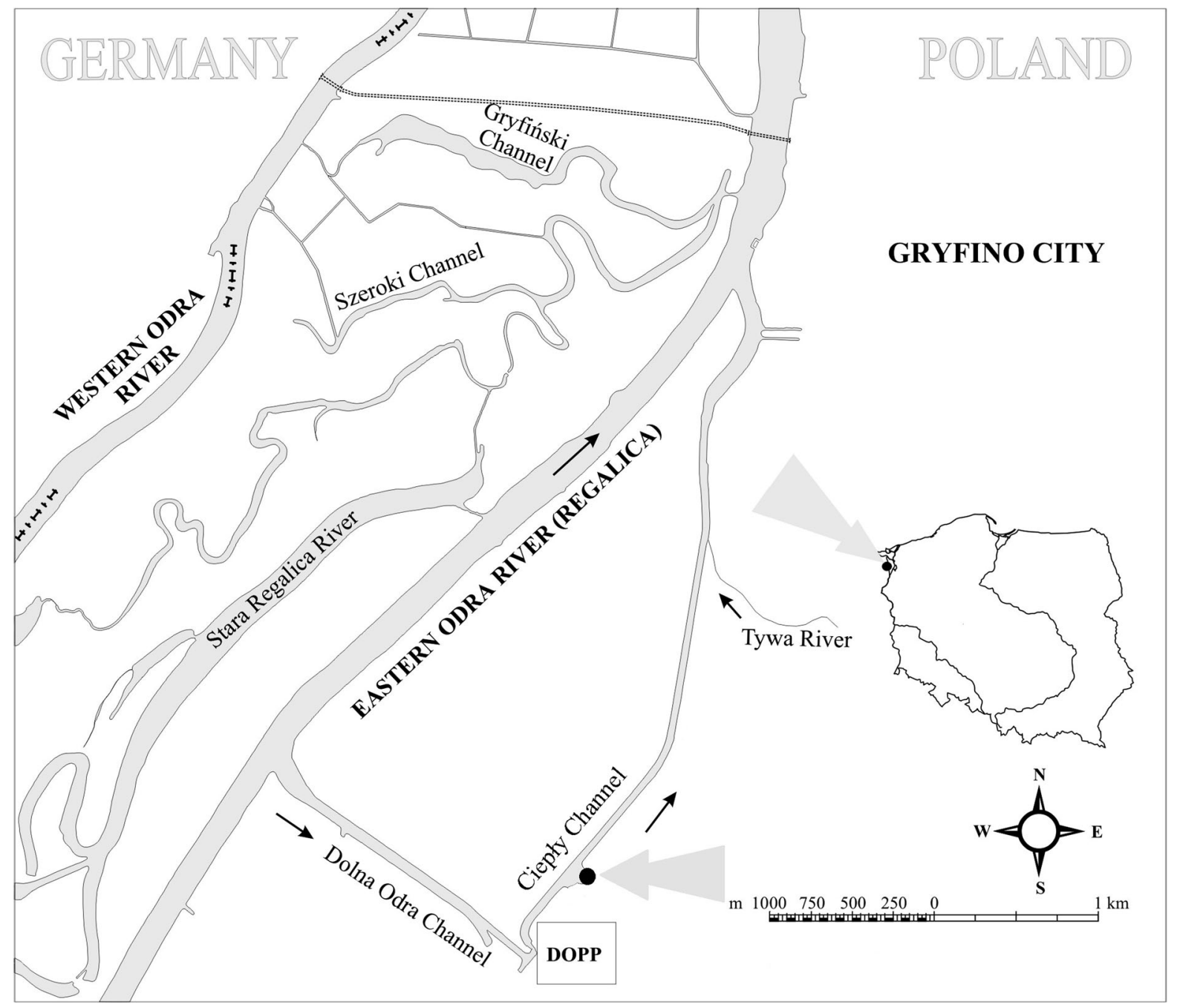

Fig. 1 Map of the Odra River branches and channels, with the sampling site indicated by the solid circle on the Ciepły Channel of the "Dolna Odra" power plant (DOPP)

fed with commercially available aquarium fish feed containing Daphnia spp.

In the field, water temperature $\left({ }^{\circ} \mathrm{C}\right)$ and dissolved oxygen content $\left(\mathrm{mg} \mathrm{O}_{2} \mathrm{dm}^{-3}\right)$ were measured with a multipurpose metre (CX-401, Elmetron, Zabrze, Poland), and $\mathrm{pH}$ and electrical conductivity $\left(\mu \mathrm{S} \mathrm{cm}^{-1}\right)$ were measured with a combination electrode.

Reproductive activity

\section{Histology}

The length of the shell was measured with an electronic calliper (Etalon, Braunschweig, Germany) to the nearest $0.01 \mathrm{~cm}$. Adductor muscles of animals were cut across, and the internal tissues were removed and preserved in a $6 \%$ solution of buffered neutral formalin (POCH, Gliwice, Poland). After preservation, a single fragment of about $10 \mathrm{~mm} \times 5 \mathrm{~mm}$ of ovary was dissected from the central part of the gonad and dehydrated in ethyl alcohol of increasing concentrations $(50,60,70,80$, and 96\%) and in butyl alcohol $(\mathrm{POCH})$. Tissues were cleared in chloroform $(\mathrm{POCH})$ and embedded in paraffin $(\mathrm{POCH})$ with wax (95\% paraffin: $5 \%$ wax). Serial 5 - $\mu$ m-thick slices were cut on a rotary microtome (RM 2155, Leica, Nussloh, Germany). Specimens were stained progressively with Ehrlich haematoxylin (Carl Roth, 
Karlsruhe, Germany) and a $1 \%$ aqueous solution of eosin Y (Fluka-Sigma Aldrich, Saint Louis, MO, USA), dehydrated in $96 \%$ ethyl alcohol and acetone $(\mathrm{POCH})$, cleared in xylene $(\mathrm{POCH})$, and mounted in DPX (POCH).

\section{Sex and sex ratio}

The sex of each individual was determined based on the presence of reproductive cells in gonads representing the female (female), male (male), or both male and female (hermaphroditic) lines. The sex ratio for all captured male and female individuals was compared with a theoretical 1:1 ratio using the $\chi^{2}$ test.

Structure of gonad, reproductive follicles activity assessment, and oogenic cells

The histological structure of gonads, ovarian activity, and phases of oocyte growth and development were analysed under a light microscope (Eclipse 80i, Nikon, Japan) configured with NIS Elements software (Nikon) and a digital camera (Digital Sight, Nikon). All statistical analyses were conducted using SPSS 16.0. software (IBM, New York, NY, USA). In ANOVA, the homogeneity of variance was checked with the Levene's test, and normality was checked with the Kolmogorov-Smirnov test.

To assess the activity of the ovaries in each female, the stage of gonadal development was identified. We used the classification proposed by Morton (1982), Dudgeon \& Morton (1983), and Juhel et al. (2003) after our modification and extension with stages $4 \mathrm{~A}-\mathrm{C}$ and $5 \mathrm{~A}-\mathrm{B}$ (Table 1). The characterization of stages included qualitative and quantitative changes in reproductive follicles and stages of oocyte growth and development.

For each month, we specified the number of females at each stage and based on this calculated the percentage of individuals at a particular stage in a monthly system. Correspondence analysis was performed to illustrate the distribution of specific stages month-by-month between 2004 and 2006. This method allowed for the identification of months showing the highest similarity in terms of advancement in gonadal development, as well as the stages that had the strongest differentiating effect on individual months.
Reproductive follicles were measured along the basement membrane using the "area polygon" function. Then the software calculated the mean diameter of the follicle, equal to the diameter of a circle with the area of the follicle area. This method helped to standardize the presentation of data on the dimensions of anatomical structures (cells, see below) with the principles used in stereological studies, where the diameter is the basic measure of size (Zieliński, 2002). The thickness of the follicle wall (the height of nurse cells, NC) was measured in line from the basal surface of nurse cells, extending from the basement membrane of the follicle, to the cell membrane of the apical part of nurse cells. Measurements were taken for 50 randomly selected follicles at stages $4 \mathrm{~A}, 4 \mathrm{~B}$, $4 \mathrm{C}, 5 \mathrm{~A}$, and $5 \mathrm{~B}$ (10 follicles per stage from 5 randomly selected individuals). Analysis was not carried out for follicles at stage 1 (insignificant sample size) or 2 and 3 (no individuals were identified at these stages).

Differences between the diameters and wall thickness of follicles at individual stages were analysed separately for diameter and thickness with two-way nested ANOVA (log-transformed data were used). The fixed factor was the type of follicle at a particular stage, and an individual mussel was a random factor (nested in the fixed factor). The post hoc LSD Fisher's test was used to analyse statistically significant results.

Previtellogenic (PVOC), vitellogenic (VOC), mature ovulated oocytes (MOC) and their atretic forms: atretic previtellogenic (aPVOC), atretic vitellogenic (aVOC), and atretic mature ovulated oocytes (aMOC) were counted in each measured follicle. Numbers of oocytes of a particular type produced by follicles at all investigated stages were tested with two-way nested ANOVA (log-transformed data were used). The fixed factor was the type of follicle at a particular stage, and an individual was a random factor (nested in the fixed factor). Separate calculations were carried out for each type of oocyte. The post hoc LSD Fisher's test was used to analyse statistically significant results.

Cells and nuclei measurements were taken for 100 PVOC and 100 MOC (10 oocytes of each type from 10 randomly selected individuals). Oocytes were measured along the plasmalemma, and nuclei along the caryolemma. Next, the diameter was calculated, and its value was used for statistical tests. The size of 
Table 1 Stages of gonadal development in S. woodiana females

\begin{tabular}{|c|c|}
\hline Stage & Gonadal development \\
\hline $\begin{array}{l}1 \text { Immature } \\
\text { (primordial) } \\
\text { or resting }\end{array}$ & $\begin{array}{l}\text { The gonad is not differentiated for sex (Fig. 4a). Gonial cells divide. This stage is characteristic for juvenile (as } \\
\text { an "immature" stage) and adult individuals (as a "resting" stage). At the initial phase of the "resting" stage, } \\
\text { the sex of adult unionids can be identified only based on scarce unresorbed oocytes generated during the } \\
\text { previous reproductive cycle }\end{array}$ \\
\hline 2 Developing & Follicles with oogonia and developing previtellogenic oocytes \\
\hline $\begin{array}{l}3 \text { Maturing } \\
\text { (growing) }\end{array}$ & Previtellogenic oocytes increase in size; vitellogenic oocytes appear \\
\hline $\begin{array}{l}4 \text { Mature } \\
\quad \text { (spawning) }\end{array}$ & $\begin{array}{l}\text { Previtellogenic and vitellogenic oocytes attached to the follicle wall via the cytoplasmic stalk and mature } \\
\text { ovulated oocytes present in the follicle lumen (Figs. 5a-c, e). Atretic oocytes with degeneration features } \\
\text { (shrunk and creased, with detectable pits in plasmalemma, vacuolized cytoplasm, eosinophilic granular } \\
\text { inclusions) present in the ovaries (Figs. } 4 \mathrm{e}, 5 \mathrm{~d}, \mathrm{f} \text { ) }\end{array}$ \\
\hline $4 \mathrm{~A}$ & Follicle walls stretched (Fig. 4b). Nurse cells tall, and their cytoplasm filled with eosinophilic granules \\
\hline 4B & Nurse cells decreased in height and the follicle walls became thinner (Fig. 4c) \\
\hline $4 \mathrm{C}$ & $\begin{array}{l}\text { The thickness of follicle walls decreased but were still stretched (Fig. 4d). Nurse cells contain residual } \\
\text { eosinophilic granules }\end{array}$ \\
\hline 5 Spent & $\begin{array}{l}\text { The ovaries contain oocytes at various developmental stages and atretic cells (Fig. 5d, f). Gonial cells began to } \\
\text { appear in the gonads }\end{array}$ \\
\hline $5 \mathrm{~A}$ & Follicles shrank and became creased and flaccid (Fig. 4e). Nurse cells form cytoplasmatic projections \\
\hline $5 B$ & $\begin{array}{l}\text { Mixed stage, with characteristics of "mature" and "immature" stages. The ovary with zones is occupied by mature } \\
\text { reproductive follicles with ovulated oocytes and regenerating germinal epithelium with gonial cells (Fig. 4f) }\end{array}$ \\
\hline
\end{tabular}

both types of oocytes was assessed only in individuals at stage 4B. Cells from this stage were chosen if two criteria were met at the same time: (i) presence of the highest number of PVOC and MOC in follicles facilitating a random selection of oocytes from the available pool and (ii) presence of the highest number of available females at stage 4B.

The size of PVOC and MOC, i.e. oocytes from the initial and final phases of development, respectively, and nuclei diameter of these cells were compared using two-way nested ANOVA. Type of cell or type of nucleus was a fixed factor, and an individual was a random factor nested within a cell type or nucleus type. Prior to the analysis, the data on cell and nucleus size were log-transformed. In addition, we calculated Pearson's correlation coefficient for the size of previtellogenic oocytes and their nuclei, and for the size of mature ovulated oocytes and their nuclei.

\section{Glochidia and brooding periods}

Females' ability to produce offspring was confirmed based on the inspection of gill demibranchs for the presence of eggs, embryos, and glochidia. Drops of the liquid content of brooding chambers were placed onto a glass slide and viewed under a light microscope (Biolar, PZO, Warsaw, Poland). Females were identified either as brooding or non-brooding. The proportion of gravid and non-gravid individuals was compared using Fisher's exact test. To increase the sample size, data collected in different years were pooled according to calendar months. Then, pairwise comparisons were performed between months.

Glochidia were isolated from the brooding chambers of 13 randomly selected females and assessed, according to Sayenko et al. (2005), for shell length and height, hinge length, and hook length. Measurements were taken for 28-31 randomly selected larvae from each female; in 8 larvae, the hook length could not be measured.

\section{Results}

Characteristics of water parameters

Water temperature in the Ciepły Channel increased from March to August (Fig. 2). In the study period, the lowest water temperature was recorded in February $2006\left(5.9^{\circ} \mathrm{C}\right)$, and the highest in August 2004 $\left(30.4^{\circ} \mathrm{C}\right)$. The mean annual temperature was $18.4^{\circ} \mathrm{C}$. 
Fig. 2 Temperature in the Ciepły Channel in the years 2004-2006

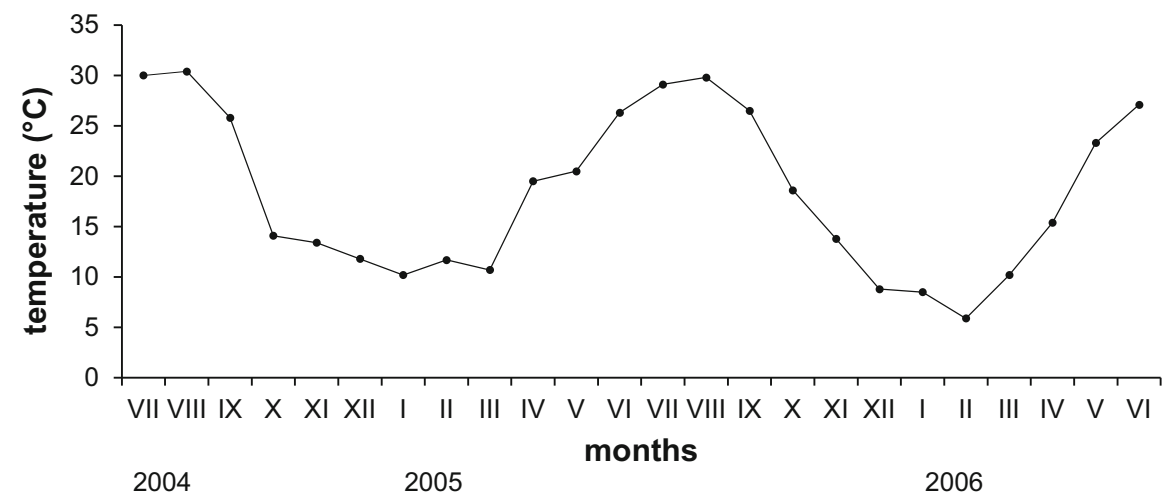

Table 2 Temperature, pH, oxygen, and conductivity in the Ciepły Channel of the "Dolna Odra" power plant in the years 2004-2006

\begin{tabular}{lclcl}
\hline & Temperature $\left({ }^{\circ} \mathrm{C}\right)$ & $\mathrm{pH}$ & Oxygen $\left(\mathrm{mg} \mathrm{O}_{2} \mathrm{dm}^{-3}\right)$ & Conductivity $\left(\mu \mathrm{S} \mathrm{cm}^{-1}\right)$ \\
\hline Mean & 18.4 & 8.2 & 9.6 & 754.9 \\
Min & 5.9 & 7.3 & 7.0 & 482.2 \\
Max & 30.4 & 9.0 & 13.1 & 943.6 \\
SD & 8.11 & 0.47 & 1.92 & 130.46 \\
\hline
\end{tabular}

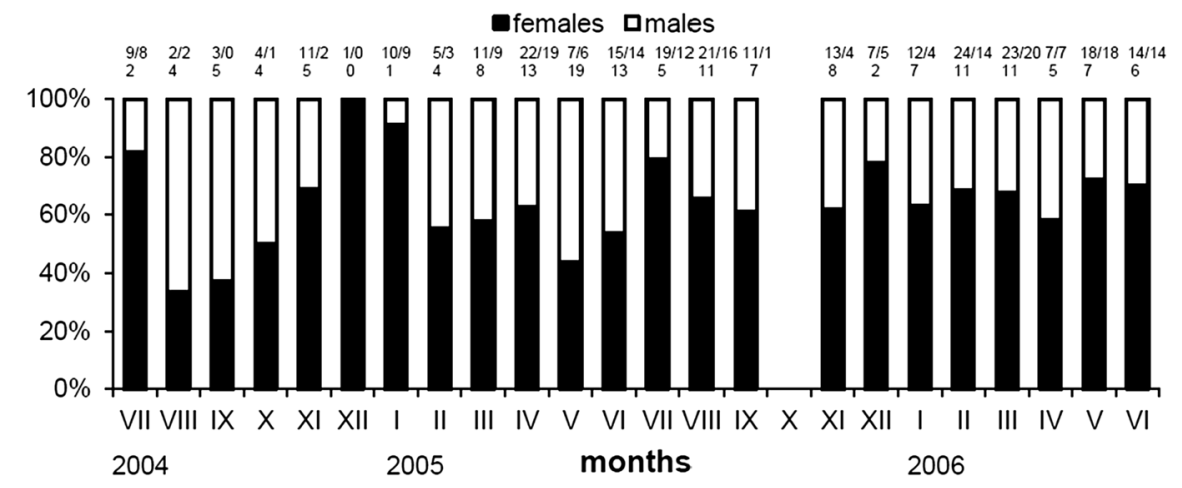

Fig. 3 Female to male sex ratio in $S$. woodiana in the years 2004-2006. (In October 2005, mussels were not captured). Information above the bars indicates exact numbers of

captured females (upper level) and males (lower level). The information on females shows the total number of females (first number) and the number of brooding females (second number)

Water in the channel did not freeze during the winter. Mean values of $\mathrm{pH}$, oxygen concentration, and electrical conductivity are presented in Table 2 .

Reproductive activity

\section{Sex and sex ratio}

Histological analysis demonstrated that of 429 captured individuals 269 were female and 148 were

male (Fig. 3). We identified 10 hermaphrodites and 2 individuals of undifferentiated sex. The sex ratio in the population of $S$. woodiana was (without individuals of undifferentiated sex) $0^{\prime \prime} \sigma^{\prime \prime} 34.66 \%$ : 우 $63 \%$ : o' $2.34 \%$. The $\chi^{2}$ test demonstrated that the female to male ratio differed significantly from the expected ratio of $1: 1 \quad\left(\chi^{2}=25.70\right.$, df $=1$, $P<0.0001)$.

The mean length of shell in the analysed females was $10.7 \mathrm{~cm}(3.15-16.8$, SD 2.74). 
Structure of gonad, oogenic cells, and reproductive follicles activity assessment

The female gonad was located at the base of the foot. In the anterior part of the body, it was adjacent to the hepatopancreas, and in this region, the penetration of hepatopancreas cells between reproductive follicles was noted. The ovary was at points infiltrated by the muscle tissue, and intrafollicular spaces were filled with haemocel (Figs. 4d, f). The wall of follicles was made of basement membrane (Fig. 5b). Nurse cells and oogenic cells extended from the internal surface of the basement membrane (Figs. $4 \mathrm{a}-\mathrm{f}, 5 \mathrm{a}-\mathrm{d}$ ).

The early previtellogenic oocytes were attached via the basal surface to the basement membrane of the follicle and were surrounded by nurse cells (Figs. 5a, b). The proximal end of the cell was wide. In this area, a cytoplasmatic stalk (foot, peduncle) was formed. During the maturing process, the shape of oocytes changed from semicircular to pear-shaped (Fig. 5a, b). The cytoplasm of oocytes was stained with haematoxylin. The mean diameter of PVOC was $14.63 \mu \mathrm{m}$ (8.46-32.02, SD 3.81), and the mean diameter of their nuclei $\left(\mathrm{PVOC}_{n}\right)$ was $8.58 \mu \mathrm{m}(5.93-12.69$, SD 1.46) (Fig. 6). The nucleus had a large and distinct nucleolus (Figs. 5a, b). The nuclei diameter increased along with the increase in PVOC diameter (Pearson's coefficient $r=0.89, P<0.0001)$. As PVOC matured, their nuclei changed position and migrated from the proximal end to the distal end of the cell.

The vitellogenic oocytes were connected via the cytoplasmatic peduncle to the basement membrane of the follicle, but the shape of the foot and cell had changed. The wide-base stalk changed into a triangular shape, with a distinct narrowing in the upper part connecting the stalk with VOC (Fig. 5c). The oocytes became spherical, and the cytoplasm was stained with eosin.

Mature ovulated oocytes were present in the follicular lumen. Such cells were spherical, polarized-with the nucleus located at the distal end-and cytoplasm was stained with eosin (Fig. 5e). The mean diameter of MOC was $85.83 \mu \mathrm{m}$ (73.32-95.82, SD 4.45), and the mean diameter of the nuclei $\left(\mathrm{MOC}_{\mathrm{n}}\right)$ was $28.95 \mu \mathrm{m}$ (21.33-34.31, SD 2.65) (Fig. 6). The size of MOC was positively correlated with the size of their nuclei (Pearson's coefficient $r=0.31, P=0.0011$ ). MOC diameter was significantly greater than PVOC diameter (ANOVA, $F_{1.18}=3347.44, P<0.0001$ ), and the diameter of $\mathrm{MOC}_{\mathrm{n}}$ was significantly greater than $\mathrm{PVOC}_{n}\left(\right.$ ANOVA, $F_{1.18}=1479.80, P<0.0001$ ) (Fig. 6).

The year long gonadal activity and maturity (stages 4) was identified, but the frequency of each stage (4A, 4B, 4C) varied between months (Fig. 7). In many cases, females at different stages of maturity $(4 \mathrm{~A}-\mathrm{C})$ and females with gonads at the "spent" stage were identified. In late summer and early autumn, $18-50 \%$ of the population were at stage 5A (Fig. 7). The presence of individuals at this stage was the strongest feature differentiating the gonadal activity in females when compared to other months (Fig. 8). On several irregular occasions, females at stage 5B were noted.

The follicles of mature females differed in terms of size and wall thickness. The largest diameter was found in follicles at stages $4 \mathrm{~B}$ and $4 \mathrm{C}$, and the thickest were at the initial stage of spawning, 4A (Fig. 9). In the analysed individuals, the number of previtellogenic, vitellogenic, and mature ovulated oocytes in the germinal epithelium of follicles fluctuated (Fig. 10a, c, e). The number of atretic oocytes in the follicles at individual developmental stages did not differ significantly between the types of follicles (Figs. 10b, d, f).

Glochidia and brooding periods

Brooding outer demibranchs were swollen. Creamcoloured gills contained eggs, embryos and, occasionally, developing glochidia (Fig. 11a, b). Brown gills contained mainly incubating glochidia, but embryos and unfertilized eggs were also found (Fig. 11c-f).

Eggs, embryos, and larvae during incubation were surrounded by a vitelline coat (Fig. 11c, e). Glochidia were triangular and asymmetric (Fig. 11e, f), with a larval thread (Fig. 11f) and a sharp claw-like hook covered with microstylets (Fig. 11g). The halves of the bivalve shell were connected with the adductor muscle (Figs. 11d-f). The mean dimensions of glochidia shells were length $258.25 \mu \mathrm{m}$ (205.69296.32, SD 14.13), height $298.91 \mu \mathrm{m}$ (233.01334.45 , SD 16.61), hinge length $206.88 \mu \mathrm{m}$ (159.86-239.59, SD 13.79), and hook length $98.32 \mu \mathrm{m}$ (50.98-156.35, SD 17.69). 


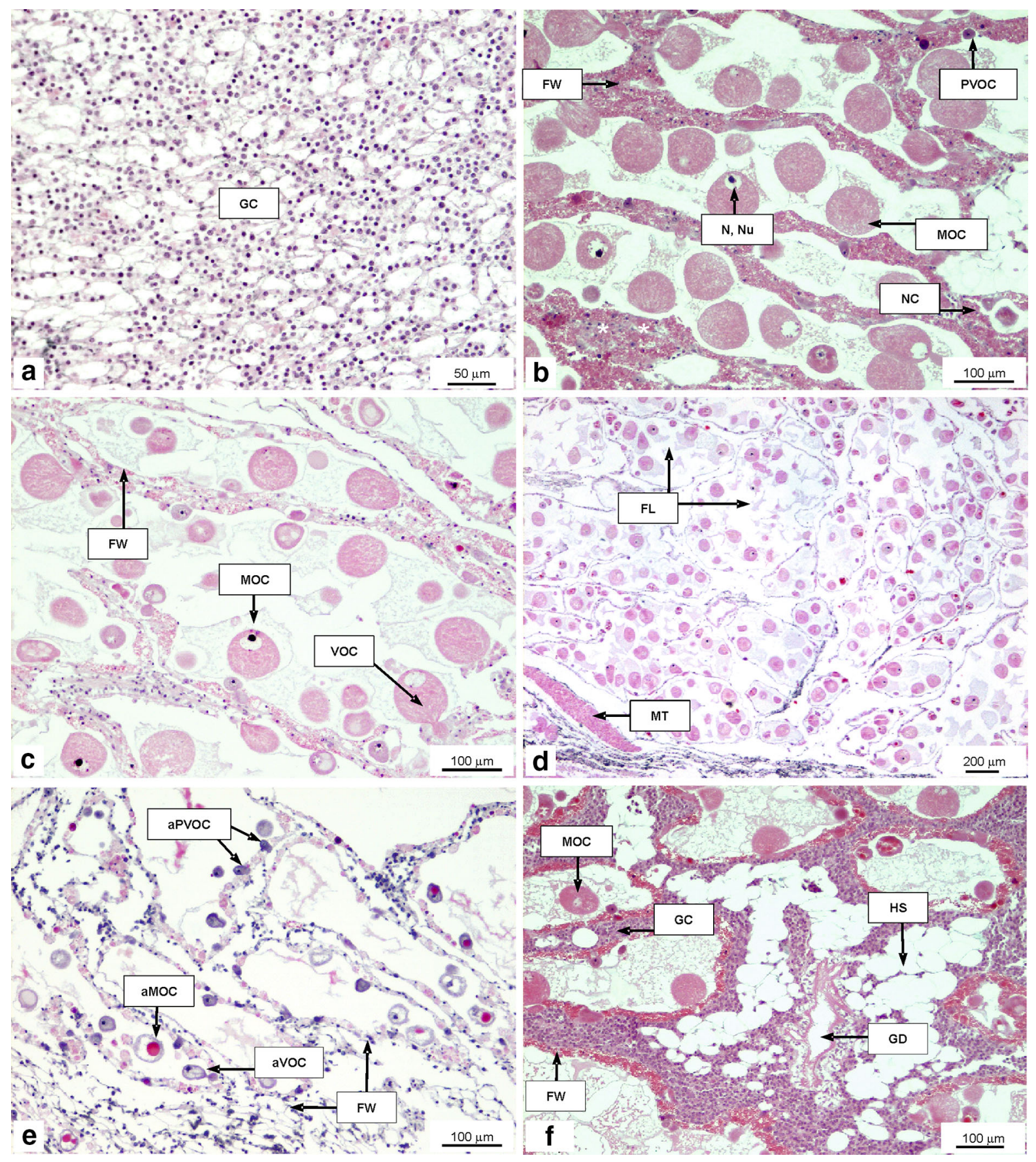

Gravid females were present for almost the whole year (except September and December 2004-small number of captured mussels). The highest numbers (and percentage share) of brooding females with respect to non-brooding ones were found from
December to August, and the lowest from September to November (Figs. 3, 12), but the significance levels in the frequency of gravid and non-gravid individuals differed between particular months (Fisher's exact tests Table 3). 
4Fig. 4 Ovaries of $S$. woodiana at different developmental stages. a Stage 1, sexually undifferentiated gonad; ovary filled with gonial cells. b Stage 4A, mature (spawning) gonad with oocytes at different developmental phases; nest of previtellogenic cells (stars) among nurse cells, thick reproductive follicle walls. c Stage 4B, mature (spawning) gonad with oocytes at different phases; thinner follicle walls. d Stage 4C, mature (spawning) gonad with oocytes at different phases. e Stage 5A, spent gonad with creased and flaccid follicles; atretic oocytes are visible in follicles. f Stage $5 \mathrm{~B}$, ovary with mature follicles and areas with gonial cells; haemocel spaces and a gonadal duct are visible. $a M O C$ atretic mature ovulated oocyte, aPVOC atretic previtellogenic oocyte, aVOC atretic vitellogenic oocyte, $F L$ follicle lumen, $F W$ follicle wall, $G C$ gonial cells, $G D$ gonadal duct, $H S$ haemocel spaces, $M T$ muscle tissue, $M O C$ mature ovulated oocyte, $N$ nucleus, $N C$ nurse cell, $N u$ nucleolus, $P V O C$ previtellogenic oocyte, VOC vitellogenic oocyte

The gonads of all brooding individuals presented different stages: 4A, 4B, 4C, 5A, and 5B. The largest female with ovulated oocytes in ovaries, and at the same time incubating offspring in the gills, had a 16.8-cm-long shell. The smallest gravid female had a 5.33-cm-long shell, and the smallest female with ovulated oocytes in follicles had a 3.15-cm-long shell.

\section{Discussion}

Habitat

The physicochemical conditions in the cooling water during the study period were similar to those reported from the second half of the 1990s (Domagała \& Kondratowicz, 2005, 2006; Domagała \& PileckaRapacz, 2007). Water temperature in the Ciepły Channel depend on the temperature in the channel providing water to the power plant, the number of operating power units, and their performance level (Domagała \& Kondratowicz, 2006). The maximum temperature, oxygen concentration, and $\mathrm{pH}$ were also similar to those observed in the Plover Cove Reservoir (Hong Kong), populated by Sinanodonta (Anodonta) woodiana (Dudgeon \& Morton 1983), but in cooling water in winter, water temperature was lower $\left(5.9-11.8^{\circ} \mathrm{C}\right)$ than in Plover Cove $\left(16^{\circ} \mathrm{C}\right)$. This may suggest that the Chinese pond mussel is tolerant to lower than previously recorded water temperature in winter, can survive this period, and even reproduce. The presence of females incubating glochidia in water of natural temperature has already been confirmed in the channels of the Odra River (Domagała et al., 2007).

Reproductive activity

\section{Sex ratio in population}

In the studied population, females outnumbered males. The dominance of females was also reported for the Plover Cove Reservoir: $9 \%$ 59.9\% : o o' 39.8\% : ợ 0.3\% (Dudgeon \& Morton, 1983; Morton, 1987). On the other hand, Soroka (2000) investigated $S$. woodiana in the Heated Konin Lakes system and reported the dominance of females only in Licheńskie Lake. Dudgeon and Morton (1983) identified the sex by the detailed analysis of histological specimens, while Soroka (2000) determined female sex on the basis of the presence of oocytes in the gonadal fluid and male sex on the basis of the absence of oocytes. The method according to Soroka (2000) is not fully reliable, as it is unsuitable for females at "immature/ resting" and even late "spent" stages. Thus, it is uncertain how many males and females could have been overlooked.

The incongruence with the 1:1 sex ratio could be explained by the theory of local mate competition (Hamilton, 1967), referring to a situation in which individuals are closely related and males compete for the same females. This would be the case in a young, recently established population. Of note is that the Plover Cove Reservoir was put into operation in 1968 (Berkowitz, 1968), and bivalves for which the sex ratio in this population was identified were collected from the end of 1979 (Dudgeon \& Morton 1983). Populations from Poland were also young (Zdanowski, 1996; Domagała et al., 2003), which was additionally confirmed by Soroka $(2005,2010)$.

Another hypothesis, still requiring detailed analysis, suggests that the dominance of females in the population from the cooling water could be explained either by mixed reproduction (sexual and asexual) or only asexual reproduction, like parthenogenesis or gynogenesis. In molluscs, parthenogenetic females are found, e.g. in the freshwater invasive snail Potamopyrgus antipodarum (Fox et al., 1996; Lively \& Jokela, 2002). Lively \& Jokela (2002) also concluded that parasites may be a factor in selecting 

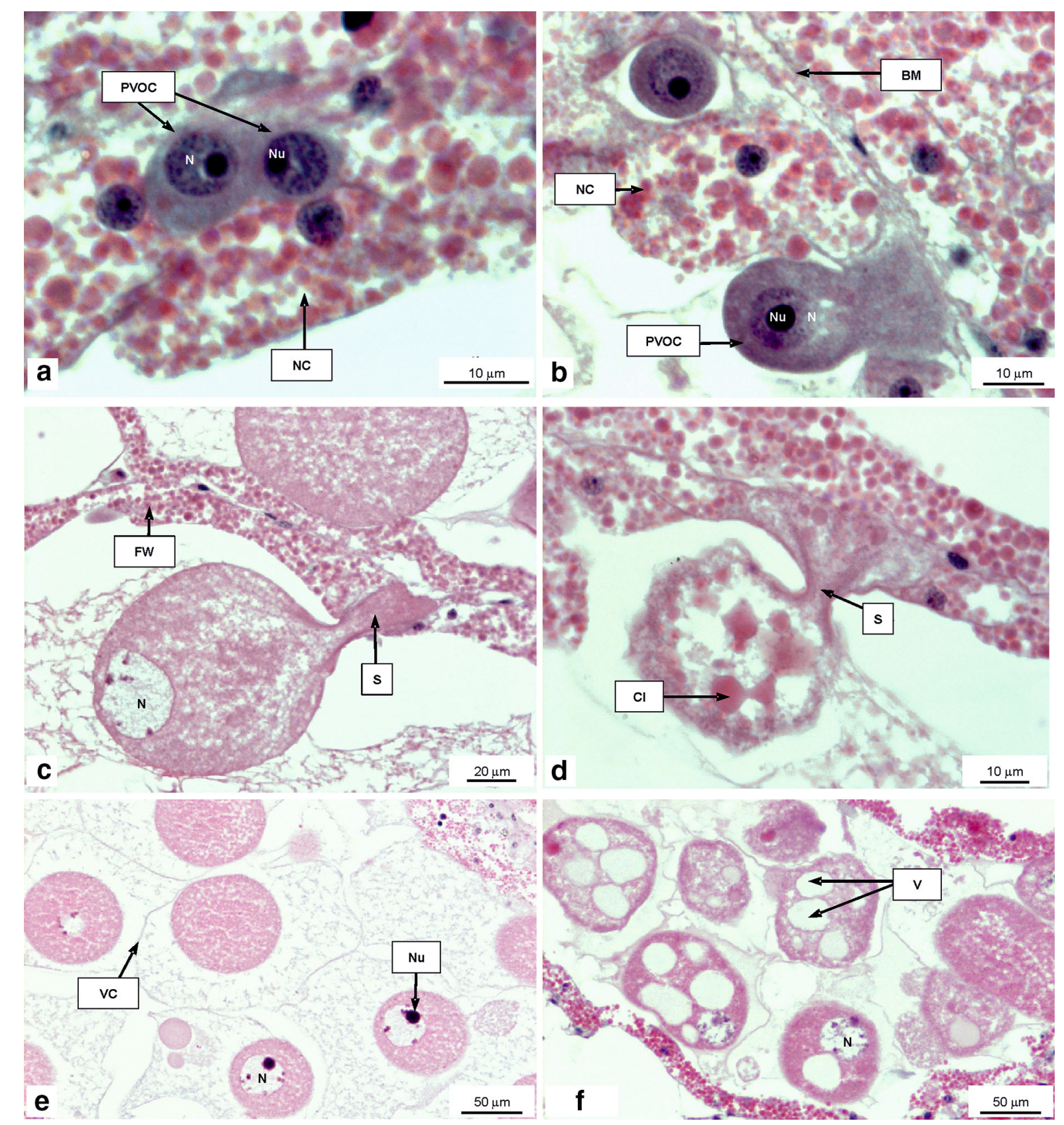

Fig. 5 Oocytes of $S$. woodiana. a Early previtellogenic oocytes surrounded by nurse cells; nucleus and huge nucleolus are visible in oocytes. b Developing pear-shaped previtellogenic oocyte. c Stalked (pedunculated) vitellogenic oocyte. d Atretic vitellogenic oocyte with cytoplasmic inclusions. e Mature ovulated oocytes surrounded by vitelline coat.

for sexual reproduction and found that the frequency of males in populations was positively correlated with the degree of parasitic infection. Occasional

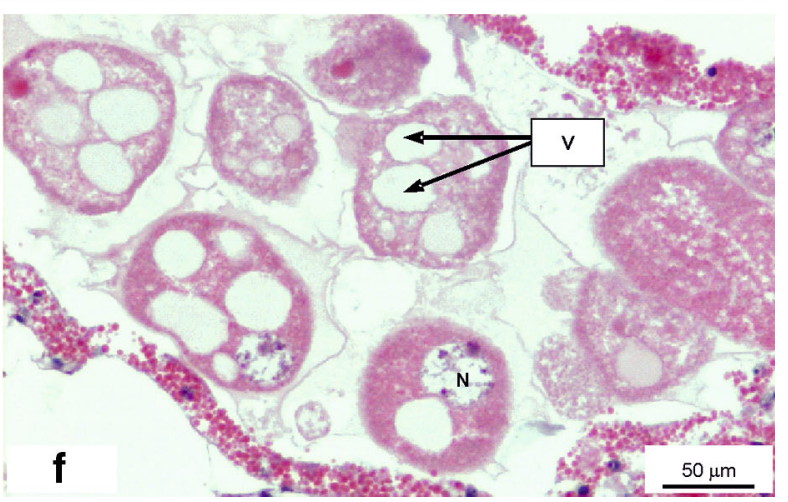

f Ovulated atretic oocytes with vacuoles in cytoplasm. $B M$ basement membrane, $C I$ cytoplasmatic inclusions, $F W$ follicle wall, $N$ nucleus, $N C$ nurse cell, $N u$ nucleolus, $P V O C$ previtellogenic oocyte, $S$ stalk of oocyte, $V$ vacuoles, $V C$ vitelline coat

infections with parasites were noticed in the Chinese pond mussel in the Ciepły Channel (Labecka, personal observations). 


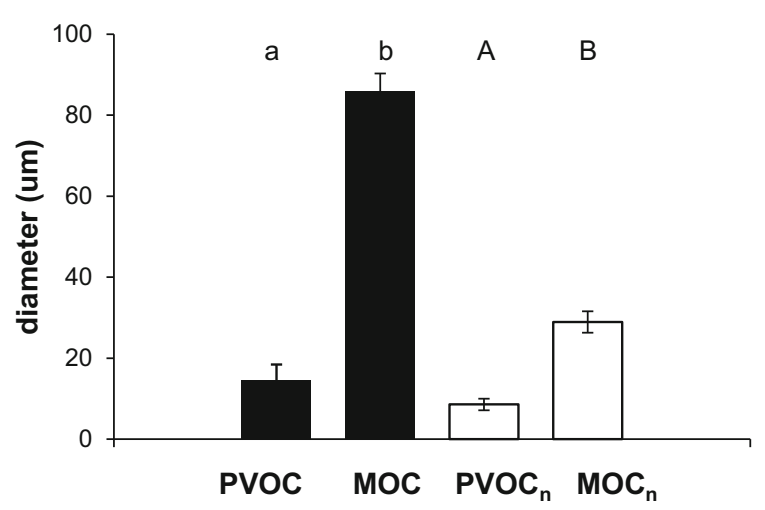

Fig. 6 PVOC Previtellogenic, $M O C$ mature ovulated oocytes, and their nuclei $\mathrm{PVOC}_{n}, \mathrm{MOC}_{n}$ diameter, respectively, $( \pm \mathrm{SD})$ in females of $S$. woodiana. Results of two-way nested ANOVA: for oocytes, $F_{1.18}=3347.44, P<0.0001$; for nuclei, $F_{1.18}=1479.80, P<0.0001$. Significance is indicated by letters above the bars

Another interesting finding is the spermatogenic pathway in $S$. woodiana males, where two types of spermatozoa were identified: typical and atypical (Łabęcka, 2009). The function of atypical spermatozoa is unclear. According to one hypothesis, the atypical spermatozoa could be involved only in the stimulation of oocytes (insemination but not fertilization), leading to the production of gynogenetic offspring (Łabęcka, 2009). Another possibility could stem from the presence of different types of mt DNA in spermatozoa developed in typical and atypical pathways. Mitochondrial genomes of such spermatozoa could be involved in the regulation of offspring sex. Shepardson et al. (2012) investigated spermatogenesis in Venustaconcha ellipsiformis and reported the presence of the M-type of $\mathrm{mt}$ genome in the mitochondria of atypical spermatozoa and the F-type of $\mathrm{mt}$ genome in typical spermatozoa. Łabęcka (2009) analysed reproduction in S. woodiana males and also noted atypical spermatogenesis leading to the formation of atypical spermatozoa, but this process was relatively less frequent than typical spermatogenesis. This phenomenon is a likely explanation for the female-biased sex ratio in the population of mussels from the cooling water.

Structure of gonad and oogenic cells

The structure of ovaries in S. woodiana was similar to that found in other Unionoidea mussels (Yokley, 1972; Grande et al., 2001; Chatchavalvanich et al., 2006; Sehriban \& Sereflisan, 2006; Hinzmann et al., 2013; Müller et al., 2015). Reproductive follicles contained nurse cells and reproductive cells in different developmental phases. In previtellogenic oocytes, the dimeters of cells and nuclei were positively correlated. This process may reflect the increase in the amount of nucleoplasm and increased synthesis of mRNA in the nucleus, followed by the transport of mRNA to the cytoplasm and preparation of the cell for vitellogenesis (Bielańska-Osuchowska, 1993). Positive staining of cytoplasm in previtellogenic oocytes with haematoxylin indicates its basophilic nature. rRNA could be synthesized in the nucleolus. The metabolic activity of the nucleouls is implied by the size of this organellum (Fig. 5a, b) (Griffond \& Bolzoni-Sungur, 1986).

Further increase in the size of the oocyte is associated with vitellogenesis-deposition of storage substances in the cytoplasm of the oocyte. Beams \& Sekhon (1966) demonstrated that vitellogenesis in Anodonta spp. takes place, inter alia, in the
Fig. 7 Percentage of gonadal stages in females of $S$. woodiana in the years 2004-2006. (In October 2005, mussels were not captured)

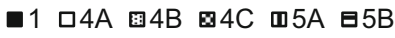

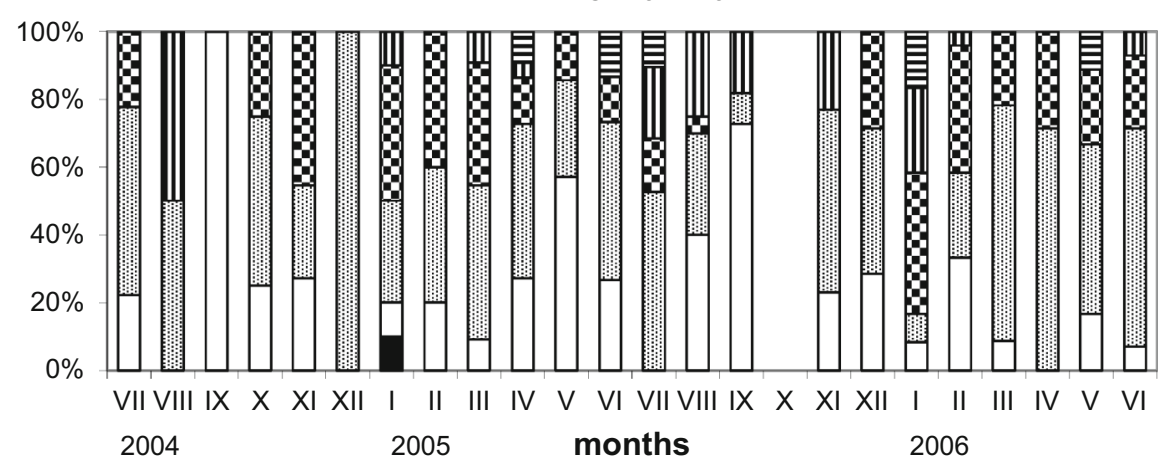




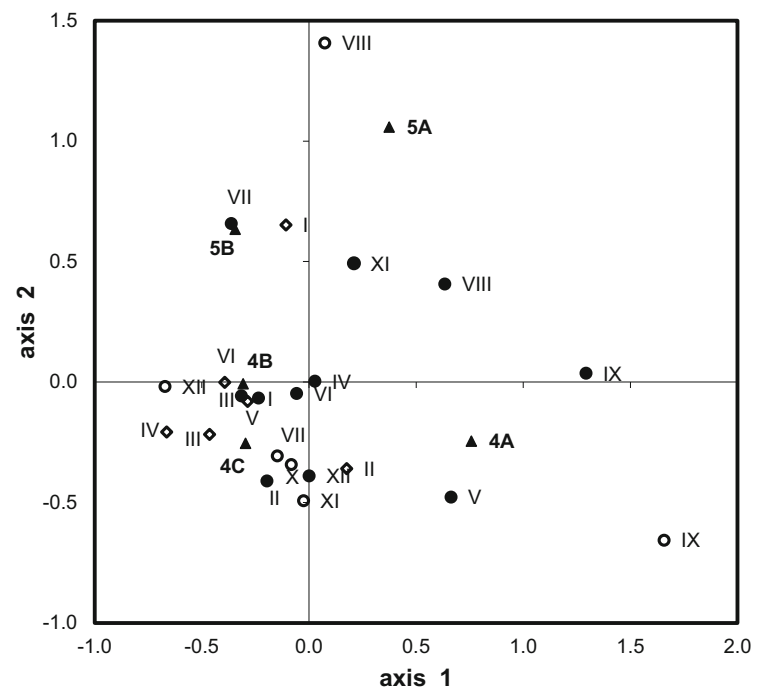

Fig. 8 Results of correspondence analysis showing the distribution of gonadal development stages in females of $S$. woodiana in the years 2004-2006. Roman numerals-investigated months; 4A, 4B, 4C, 5A, and 5B connected with solid triangles stages of gonadal development; opened circle 2004 year, solid circle 2005 year, opened rhombus 2006 year. Axes 1 and 2 explained 40.59 and $27.06 \%$, respectively

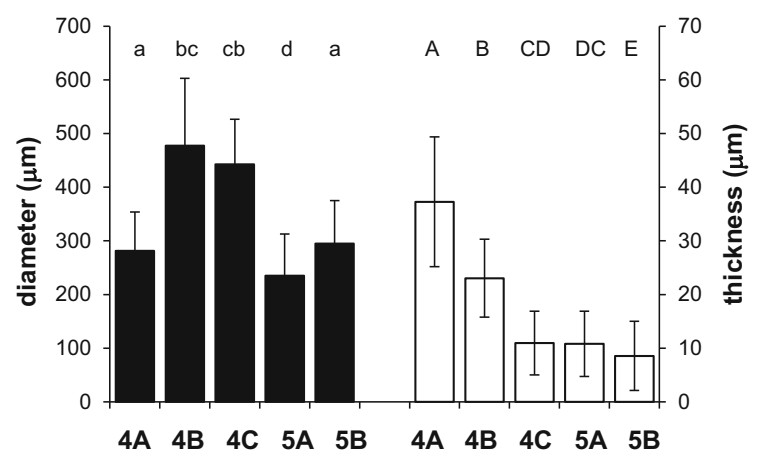

Fig. 9 Diameter and thickness $( \pm \mathrm{SD})$ of reproductive follicles at different stages of gonadal development (4A, 4B, 4C, 5A, and $5 \mathrm{~B}$ ) in females of $S$. woodiana. Results of two-way nested ANOVA with post hoc Fisher's test (significance is indicated by letters above the bars): for diameter $F_{4.20}=21.59$, $P<0.0001$; for thickness, $F_{4.20}=15.96, P<0.0001$

cytoplasm and Golgi apparatus, and the endoplasmic reticulum is involved in this process. Unionid oocytes elongate towards the follicular cavity, and a narrow stalk rich in microtubules is formed at the base of the cell simultaneously (Beams \& Sekhon, 1966; Pipe, 1987; Focarelli et al., 1990). Microtubules probably form channels used for the transport of additional nutrients from nurse cells to the oocytes (Beams \& Sekhon, 1966). In nurse cells of Margaritifera margaritifera Hanstén et al. (1997) identified, for example, PAS-positive protein-glycoprotein granules. Our study revealed that the cytoplasm of nurse cells contained eosinophilic (acidophilic) granules. In $S$. woodiana, we also observed a reduced wall thickness in follicles (height of NC) in subsequent stages of gonadal development (Fig. 9). This process could suggest that storage substances accumulated in nurse cells were transported via the stalk to the cytoplasm of oocytes (Fig. 5c). Mature oocytes rich in storage substances detached from the wall of the follicle and filled the follicular lumen (Fig. 5e). According to Focarelli et al. (1990), the differentiation of the vitelline coat is completed once the oocyte is free from the stroma.

In the Chinese pond mussel at the "mature" and "spent" stages, the number of atretic oocytes of each type was relatively stable. In previous studies carried out on Unionidae mussels, atretic cells were only described at "postspawning" stages (Şehriban \& Şereflişan, 2006; Lima et al., 2012), but oocyte degeneration and resorption was noticed earlier in marine bivalve species like Mytilus edulis and Pecten maximus. Pipe (1987) and Dorange \& Le Pennec (1989) analysed atretic oocytes and identified vacuolized cytoplasm, disrupted plasmalemma, and enlarged perivitelline space. Dorange \& Le Pennec (1989) also pointed out pouches in the nuclear membrane, damaged cell membrane, discontinuous yolk sac, and the release of cell content to the intrafollicular space. Eosinophilic granules in the cytoplasm of atretic oocytes in Hyridella depressa were mentioned by Byrne (1998). Some of these characteristics were also identified in $S$. woodiana.

The cause of cell degeneration has not been explained. Possibly, it may result from resorption controlling the number of cells in a follicle, or a selfcleaning process through which the gonad could prepare itself for a new sexual cycle (postspawning resorption). Unfavourable environmental conditions can also induce gametolysis (Motavkine \& Varaksine 1989).

Reproductive follicles activity assessment

Changes in temperature and availability of food are important factors inducing gonadal development and 

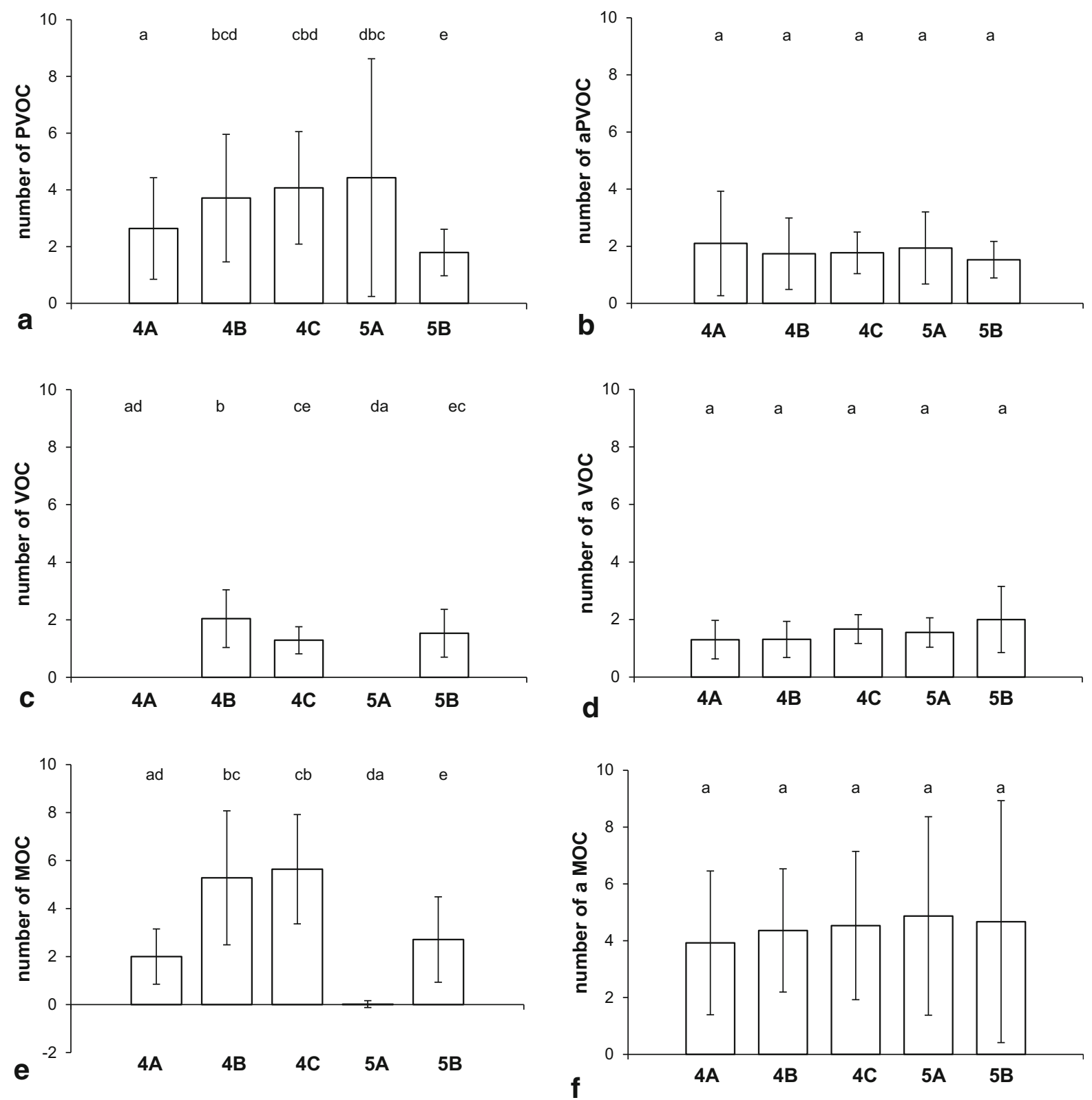

Fig. 10 Number $( \pm$ SD) of oocytes in follicles at different stages of gonadal development in females of $S$. woodiana. a $P V O C$ previtellogenic, b $a P V O C$ atretic previtellogenic, c $V O C$ vitellogenic, d $a V O C$ atretic vitellogenic, e $M O C$ mature ovulated, f $a M O C$ atretic mature ovulated. Results of two-way nested ANOVA with post hoc Fisher's test: for

PVOC, $F_{4.20}=4.61, P=0.008$; for aPVOC, $F_{4.20}=0.44$, $P=0.8$; for VOC, $F_{4.20}=21.39, P<0.0001$; for aVOC, $F_{4.20}=0.93, P=0.5$; for MOC, $F_{4.20}=56.95, P<0.0001$; for aMOC, $F_{4.20}=0.16, P=0.95$. Significance is indicated by letters above the bars

gametogenic transformations in cold-blooded animals (MacDonald \& Thompson, 1985; Juhel et al., 2003; Galbraith \& Vaughn, 2009). Bivalves of the temperate zone living in reservoirs of a natural temperature

regimen show seasonal gonadal activity (Domagała, 1997), but in other climates, their reproduction can diverge from this pattern. For instance, in Hyriopsis bialatus, all stages of gametogenesis were observed 

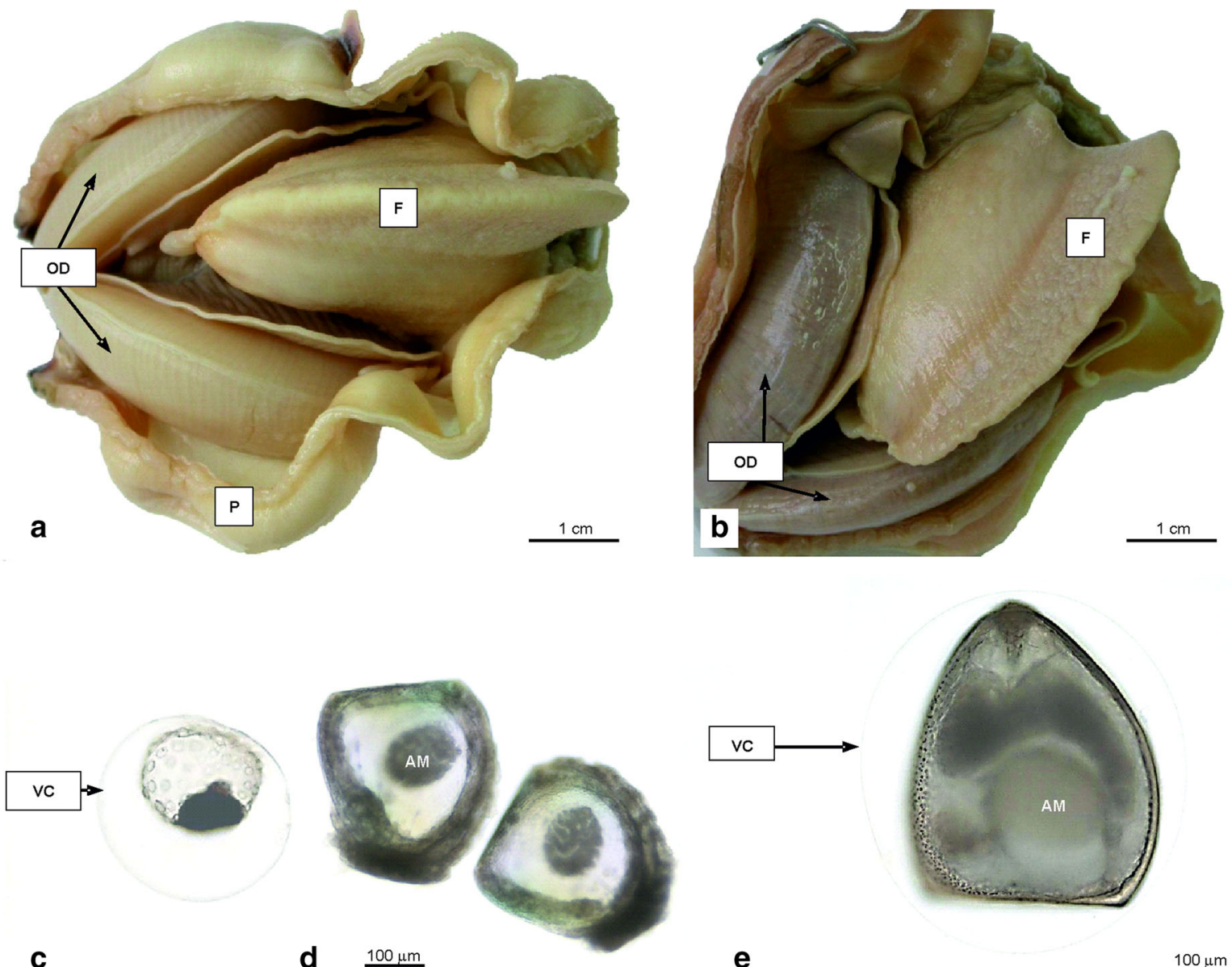

C

d $\quad 100 \mu \mathrm{m}$

e

$100 \mu \mathrm{m}$
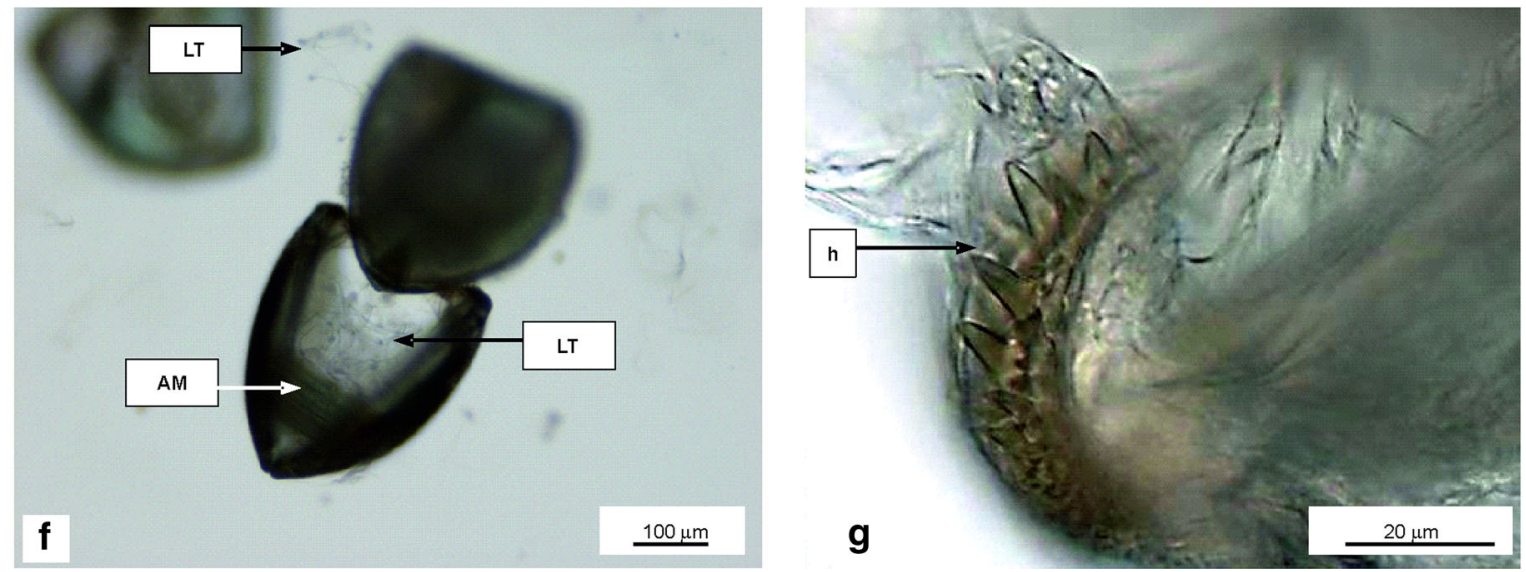

Fig. 11 a, b Brooding females of $S$. woodiana with glochidia. e, f Mature glochidia. $\mathbf{g}$ Hook of glochidium with demibranchs filled mainly with eggs and embryos (a), microstylets. $A M$ adductor, $F$ foot muscle, $h$ hook, $L T$ larval glochidia (b). c Embryo in vitelline coat. d Developing thread, $O D$ outer demibranchs, $P$ pallium, $V C$ vitelline coat 


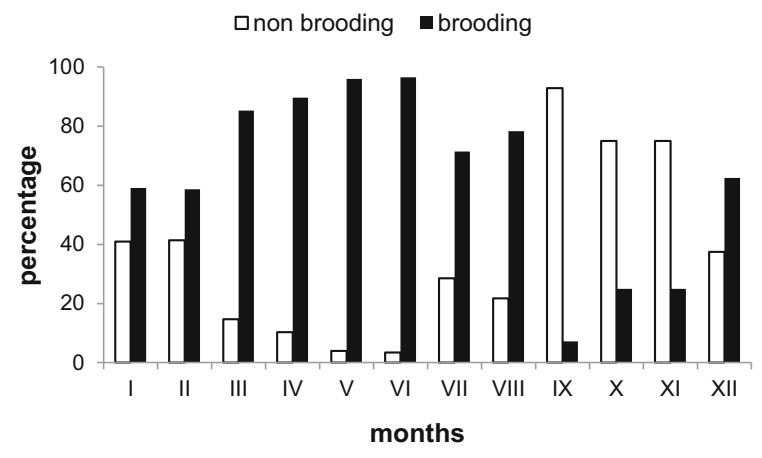

Fig. 12 Percentage of brooding and non-brooding females of S. woodiana

throughout the year, suggesting the continuous development of germ cells (Chatchavalvanich et al., 2006). Dudgeon \& Morton (1983) also reported the all year long gonadal activity of $S$. woodiana.

The Chinese pond mussels from the cooling water showed all year long multiple ovulation. Each month, partial spawning occurred in mature females (mature and previtellogenic cells were always present). On several occasions, individuals at the mixed stage of gonadal development (5B) were noted. This process can suggest an increased reproductive effort in females who simultaneously ovulated and regenerated the lineage of reproductive cells. The continuous reproduction of $S$. woodiana may undoubtedly contribute to the increase in the size of the mussel population and colonization success in this species. The observed gonadal activity predisposes females to the interrupted production of glochidia and their sequential release into the environment by different individuals in asynchronic fashion.

How can we explain the characteristics of the reproductive cycle in the Chinese pond mussel in cooling water? Because of the differing number of power units operating in the power plant, and the discharge of cooling water at different time intervals, the temperature of water in the Ciepły Channel is relatively unstable. According to Sîrbu et al. (2005) and Corsi et al. (2007), S. woodiana is physiologically predisposed to function in harsh environmental conditions. Byrne et al. (2000) claimed that the constant presence of mature oocytes in gonads could explain the adaptation of mussels to unstable environmental conditions. In cooling water, after a period of unfavourable conditions and, for example, increased mortality of released larvae, such asynchronous and partial spawning observed in $S$. woodiana could allow females to further deposit eggs in gills. After fertilization and larvae development, the next generation clutch of glochidia would be released into the water.

It should also be mentioned that in the cooling water of the "Dolna Odra" power plant there are fish farming cage systems, where fish are fed with industrial fodder. Perhaps the supplied fodder affects the trophy level in the river strongly enough to create a habitat suitable for $S$. woodiana. Byrne (1998), who investigated different populations of $H$. depressa, also found continuous gametogenesis in this species in

Table 3 Results of Fisher's exact test ( $P$ values) which compared the frequency of brooding and non-brooding $S$. woodiana females between months

\begin{tabular}{|c|c|c|c|c|c|c|c|c|c|c|c|}
\hline Months & I & II & III & IV & $\mathrm{V}$ & VI & VII & VIII & IX & X & XI \\
\hline \multicolumn{12}{|l|}{ I } \\
\hline II & 1.0000 & & & & & & & & & & \\
\hline III & 0.0554 & $0.0237 *$ & & & & & & & & & \\
\hline IV & $0.0184^{*}$ & $0.0148^{*}$ & 0.7156 & & & & & & & & \\
\hline V & $0.0032 *$ & $0.0014 *$ & 0.2283 & 0.1625 & & & & & & & \\
\hline VI & $0.0012^{*}$ & $0.0010^{*}$ & 0.2050 & 0.6115 & 1.0000 & & & & & & \\
\hline VII & 0.3857 & 0.4077 & 0.2204 & 0.1027 & $0.0264 *$ & $0.0119 *$ & & & & & \\
\hline VIII & 0.2078 & 0.1521 & 0.5036 & 0.4411 & 0.0912 & 0.0762 & 0.7490 & & & & \\
\hline IX & $0.0021 *$ & $0.0023^{*}$ & $0.0000 *$ & $0.0000^{*}$ & $0.0000^{*}$ & $0.0000 *$ & $0.0002 *$ & $0.0000 *$ & & & \\
\hline $\mathrm{X}$ & 0.3061 & 0.3083 & $0.0237 *$ & $0.0136^{*}$ & $0.0043 *$ & $0.0029 *$ & 0.1055 & 0.0646 & 0.4052 & & \\
\hline XI & $0.0349 *$ & $0.0251^{*}$ & $0.0000 *$ & $0.0000 *$ & $0.0000 *$ & $0.0000 *$ & $0.0019^{*}$ & $0.0004 *$ & 0.2265 & 1.0000 & \\
\hline XII & 1.0000 & 1.0000 & 0.1625 & 0.1010 & $0.0359 *$ & $0.0256^{*}$ & 0.6781 & 0.3931 & $0.0109 *$ & 0.5455 & 0.0877 \\
\hline
\end{tabular}

Asterisk indicates $P$ values $<0.05$ 
eutrophic reservoirs, but seasonal gametogenesis in oligotrophic sites.

\section{Characteristics of glochidia}

Larvae of the Chinese pond mussel differed from glochidia produced by Unionidae spp. found in European waters in terms of shape and size of larval shell (Pekkarinen \& Englud, 1995a, b). Glochidia of $S$. woodiana from Poland, compared to the larvae of $A$. woodiana from Japan and Anodonta amurensis from Far Eastern Russia, were similar considering the values of a single metric feature of the shell: height (Kondo, 1987) or length (Sayenko et al., 2005; Sayenko \& Soroka 2013). Unfortunately, phylogenetic data are still unavailable to clarify if unionids of Anodonta spp. indigenous in Asia, sometimes reported as Sinanodonta, represent the same or different species. However, considerable differences in the morphology of mussels living in the Heated Konin Lakes system in zones of different temperature and water flow rates suggests that adult mussels, depending on environmental conditions, show high plasticity in terms of the shape and size of their shell (Soroka \& Zdanowski, 2001) which can also be observed in their larvae.

The hooks of $S$. woodiana glochidia probably help the larvae to attach more effectively to fish and to increase the number of sites for encystation ( Labęcka, 2009). The presence of the larval thread is probably associated with the formation of a structure preventing the glochidia from sinking to the bottom, and thus prolonging floating in water until the fish host is found. This thread could have a function similar to silk threads in ballooning spiders. In European representatives of the Unionidae, a larval thread was not found in Pseudanodonta complanata or Unio crassus-species preferring lothic water. However, it was identified in Unio tumidus, Unio pictorum, A. cygnea, and A. anatina (Pekkarinen \& Englund, 1995b; Pekkarinen, 1996; Wächtler et al., 2001). The Chinese pond mussel in the Ciepły Channel inhabited sites of slow water flow (Skuza et al., 2009), and in many other sites in Poland, such as calm-flowing river canals and ponds (Domagała et al., 2007; Spyra et al., 2012).

\section{Brooding periods}

Depending on the environmental conditions, the brooding period and the duration of encystation on a fish body may differ in mussels, even of the same species (Piechocki, 1969, 1999; Dudgeon \& Morton, 1984; Watters \& O’Dee, 1999, 2000; Hinzmann et al., 2013). In the Asian populations of $S$. woodiana, gravid females were found almost all year (except for August and October) (Dudgeon \& Morton, 1983) and from February to August (Kondo, 1987). In the Plover Cove Reservoir, the number of individuals incubating glochidia decreased below 30\% in autumn and winter (Dudgeon \& Morton, 1983), while in the Ciepły Channel-below 25\%. In one site in Europe, in the Kyjovka River (Czech Republic), mature glochidia in gills were detected from April to September and immature glochidia from December to August (Douda et al., 2012). For comparison, in cooling water, the brooding females were found all year round (Fig. 12). Individuals produced mature oocytes in portions and showed asynchronic gonadal activity. This type of ovulation of mature cells predisposes females to the continuous production of larvae and their partial release by different individuals in asynchronic fashion. Mussels were characterized by tachytictic incubation (individuals were short-term brooders) and a mixed way of offspring overwintering (parent and host overwintering) (Łabęcka, 2009). This was also confirmed by preliminary observations on fish: common rudd Scardinius erythrophthalmus, pumpkinseed Lepomis gibbosus and white bream Blicca bjoerkna (Łabęcka, 2009).

Interestingly, some of the analysed reproducing females had relatively small shells. Dudgeon \& Morton (1983), and Kondo (1987) also reported small mature and brooding females. It is known that the Unionidae are characterized by undetermined growth and continue it after reaching sexual maturity. The fact that mussels of small body size reach reproductive maturity can be associated with living in an environment where seasonal or other types of variations occur (Müller et al., 2012). For example, changes in the water level were recorded in the Plover Cove Reservoir and unstable temperature in the cooling water. It should be pointed out that the water in the Ciepły Channel is also affected by flood waves formed locally and in the upper section of the Odra River after winter snowmelt and rainfall. The backflow of saline water from the Gulf of Pomerania, which adjoins the Baltic Sea, and increases or decreases in water levels caused by wind, has also been reported (Buchholz, 1993; Tórz, 2002). 


\section{Conclusions}

Thermal pollution of water can affect biodiversity and cause changes in the reproductive behaviour of native fauna (Formicki et al., 2006; Domagala et al., 2015). For thermophilic animals from other climatic zones, heated water that generated by industry can create suitable conditions for life, and also for continuous reproduction, as demonstrated in this study. The analysis of the reproductive potential of mussel species using the example of $S$. woodiana can help to forecast potential threats caused by accidentally introduced species. Their excessive reproduction may become a factor limiting the availability of free ecological niches for native species and could also influence the formation of new habitats (Meneghetti et al., 2004; Werner \& Rothhaupt, 2007). Therefore, more detailed ecological studies are necessary to investigate changes in the population size and density of these mussels, and interactions with other species living in the cooling water of the Odra River.

Open circuits of cooling water should be continuously monitored for the distribution of alien species, particularly near protected areas (e.g. the mouth of the Ciepły Channel adjoining the border of the "Dolna Odra River Valley" Landscape Park). Currently, warm short winters when no ice cover is formed on water reservoirs are increasingly frequent in Poland. Such environmental conditions promote the colonization of natural waters by species arriving from warm climatic zones and their further expansion (Domagała et al., 2007).

Acknowledgments The research was financed by the Polish Ministry of Scientific Research and Information Technology (Grant to A.M.L., No. NN303 068 32/2367) and supported by the Institute of Environmental Sciences, Jagiellonian University (DS/WBiNoZ/INoŚ/757/015 and K/ZDS/005386). H. Łabęcka, W. Łabęcki, B. Migdalska, M. Pilecka-Rapacz, K. Woźniak, and P. Brocka helped with field logistics. We thank J. Kobak for statistical advice, and M. Czarnołęski, T. Müller, N. Szabla, and A. Walczyńska for comments on earlier versions of the manuscript. We are grateful to two anonymous reviewers for their suggestions to improve our work.

Author's contribution A.M.L. and J.D. designed the study and collected mussels. A.M.L. planned, developed, and performed all procedures and analyses, interpreted results, and wrote the manuscript. All of the authors reviewed the manuscript.

\section{Compliance with Ethical Standards}

Conflicts of interest The authors declare no conflicting interests.

Open Access This article is distributed under the terms of the Creative Commons Attribution 4.0 International License ( http://creativecommons.org/licenses/by/4.0/), which permits unrestricted use, distribution, and reproduction in any medium, provided you give appropriate credit to the original author(s) and the source, provide a link to the Creative Commons license, and indicate if changes were made.

\section{References}

Alexandrowicz, S. W., 1993. Water snails introduced into the Botanic Garden in Cracow. Folia Malacologica 5: 109113.

Allendorf, F. W. \& L. L. Lundquist, 2003. Introduction: population biology, evolution, and control of invasive species. Conservation Biology 17: 24-30.

Barnhart, M. C., W. R. Haag \& W. N. Roston, 2008. Adaptations to host infection and larval parasitism in Unionoida. Journal of the North American Benthological Society 27: 370-394.

Beams, H. W. \& S. S. Sekhon, 1966. Electron microscope studies on the oocyte of the fresh-water mussel (Anodonta), with special reference to the stalk and mechanism of yolk deposition. Journal of Morphology 119: 477-501.

Beran, L., 1997. First record of Sinanodonta woodiana (Mollusca: Bivalvia) in the Czech Republic. Acta Societatis Zoologicae Bohemicae 61: 1-2.

Berkowitz, M., 1968. Plover Cove village to Taipo Market: a study in forced migration. Journal of Hong Kong Branch of the Royal Asiatic Society 8: 96-108.

Bielańska-Osuchowska, Z., 1993. Embriologia. Państwowe Wydawnictwo Rolnicze i Leśne, Warszawa.

Buchholz, W., 1993. Hydrografia i hydrologia Dolnej Odry. In Jasnowska, J. (ed.), Stan środowiska miasta i rejonu Szczecina. Szczecińskie Towarzystwo Naukowe, Szczecin: $45-48$.

Byrne, M., 1998. Reproduction of river and lake populations of Hyridella depressa (Unionacea: Hyriidae) in New South Wales: implications for their conservation. Hydrobiologia 389: 29-43.

Byrne, M., H. Phelps, T. Church, V. Adair, P. Selvakumaraswamy \& J. Potts, 2000. Reproduction and development of the freshwater clam Corbicula australis in southeast Australia. Hydrobiologia 418: 185-197.

Cappelletti, C., S. Cianfanelli, M. E. Beltrami \& F. Ciutti, 2009. Sinanodonta woodiana (Lea, 1834) (Bivalvia: Unionidae): a new non-indigenous species in Lake Garda (Italy). Aquatic Invasions 4: 685-688.

Chatchavalvanich, K., P. Jindamongkon, U. Kovitvadhi, A. Thongpan \& S. Kovitvadhi, 2006. Histological structure of gonads in the freshwater pearl mussel, Hyriopsis (Hyriopsis) bialatus Simpson, 1900. Invertebrate Reproduction and Development 49: 245-253. 
Corsi, I., A. M. Pastore, A. Lodde, E. Palmerini, L. Castagnolo \& S. Focardi, 2007. Potential role of cholinesterases in the invasive capacity of the freshwater bivalve, Anodonta woodiana (Bivalvia: Unionacea): a comparative study with the indigenous species of the genus, Anodonta sp. Comparative Biochemistry and Physiology - Part C: Toxicology \& Pharmacology 145: 413-419.

Domagała, J., 1997. Annual reproductive cycle of the females of Dreissena polymorpha (Pall.) from lake Inulec. Polish Archives of Hydrobiology 44: 467-475.

Domagała, J. \& A. Kondratowicz, 2005. Porównanie wybranych wskaźników fizyko-chemicznych wód kanału doprowadzającego i odprowadzającego Elektrowni Dolna Odra w latach 2000-2002. Zeszyty Naukowe Wydziału Budownictwa i Inżynierii Środowiska Politechniki Koszalińskiej. Seria: Inżynieria Środowiska 22: 741-750.

Domagała, J. \& A. Kondratowicz, 2006. Warunki środowiskowe wód kanałów zimnego i ciepłego Elektrowni „Dolna Odra” w drugiej połowie lat 90-tych. Rocznik Ochrona Środowiska, Środowiskowo-pomorskie Towarzystwo Naukowe Ochrony Środowiska 8: 355-360.

Domagała, J. \& M. Pilecka-Rapacz, 2007. Charakterystyka wód pochłodniczych Elektrowni Dolna Odra w latach 2004-2006. Zeszyty Naukowe Wydziału Budownictwa i Inżynierii Środowiska Politechniki Koszalińskiej. Seria: Iżynieria Środowiska 23: 751-760.

Domagała, J., B. Migdalska, A. M. Łabęcka \& M. PileckaRapacz, 2003. Anodonta woodiana (Lea, 1834) na Pomorzu Zachodnim. Acta Biologica Uniwersytetu Szczecińskiego 10: 199-202.

Domagała, J., A. M. Łabęcka, B. Migdalska \& M. PileckaRapacz, 2007. Colonisation of the channels of Międzyodrze (north-western Poland) by Sinanodonta woodiana (Lea, 1834) (Bivalvia: Unionidae). Polish Journal of Natural Sciences 22: 679-690.

Domagala, J., L. Kirczuk, K. Dziewulska \& M. Pilecka-Rapacz, 2014. Annual development of gonads of pumpkinseed, Lepomis gibbosus (Actinopterygii: Perciformes: Centrarchidae) from a heated-water discharge canal of a power plant in the lower stretch of the Oder river, Poland. Acta Ichthyologica at Piscatoria 44: 131-143.

Domagala, J., L. Kirczuk \& M. Pilecka-Rapacz, 2015. Annual development cycle of gonads of bream (Abramis brama $\mathrm{L}$. 1758) females from the lower Oder River sections influenced differently by the heated effluents from a power station. Journal of Applied Ichthyology 31(Supplement): $41-48$.

Dorange, G. \& M. Le Pennec, 1989. Ultrastructural study of oogenesis and oocytic degeneration in Pecten maxiums from the Bay of St. Brieuc. Marine Biology 103: 339-348.

Douda, K., M. Vrtílek, O. Slavík \& M. Reichard, 2012. The role of host specificity in explaining the invasion success of the freshwater mussel Anodonta woodiana in Europe. Biological Invasions 14: 127-137.

Dudgeon, D. \& B. Morton, 1983. The population dynamics and sexual strategy of Anodonta woodiana (Bivalvia: Unionacea) in Plover Cove Reservoir, Hong Kong. Journal of Zoology, London 201: 161-183.

Dudgeon, D. \& B. Morton, 1984. Site selection and attachment duration of Anodonta woodiana (Bivalvia: Unionacea) glochidia on fish hosts. Journal of Zoology, London 204: 355-362.

Focarelli, R., D. Rosa \& F. Rosati, 1990. Differentiation of the vitelline coat and the polarized site of sperm entrance in the egg of Unio elongatulus (Mollusca, Bivalvia). Journal of Experimental Zoology 254: 88-96.

Formicki, K., A. Korzelecka-Orkisz, A. Sobociński, A. Tański \& A. Winnicki, 2006. Wpływ podwyższonej termiki wody na rozród rodzimej ichtiofauny. In Trzebiatowski, R. (ed.), Stan jakości wód pochłodniczych Elektrowni Dolna Odra i ich wpływ na zdrowotność i wyniki chowu ryb w latach 2004-2005. Agriculture Univeristy in Szczecin, Szczecin: 93-100.

Fox, J. A., M. F. Dybdahl, J. Jokela \& C. M. Lively, 1996. Genetic structure of coexisting sexual and clonal subpopulations in a freshwater snail (Potamopyrgus antipodarum). Evolution 50: 1541-1548.

Galbraith, H. S. \& C. C. Vaughn, 2009. Temperature and food interact to influence gamete development in freshwater mussels. Hydrobiologia 636: 35-47.

Giradi, H. \& J.-C. Ledoux, 1989. Présence d'Anodonta woodiana (Lea) en France (Mollusques, Lamellibranches, Unionidae). Bulletin Mensuel de la Société Linnéenne de Lyon 58: 286-290.

Graf, D. L. \& D. Ó. Foighil, 2000. The evolution of brooding characters among the freshwater pearly mussels (Bivalvia: Unionoidea) of North America. Journal of Molluscan Studies 66: 157-170.

Grande, C., R. Araujo \& M. A. Ramos, 2001. The gonads of Margaritifera auricularia (Spengler, 1793) and Margaritifera margaritifera (Linnaeus, 1758) (Bivalvia: Unionidea). Journal of Molluscan Studies 67: 27-35.

Griffond, B. \& D. Bolzoni-Sungur, 1986. Stages of oogenesis in the snail, Helix aspersa: cytological, cytochemical and ultrastructural studies. Reproduction Nutrition Development 26: 461-474.

Hamilton, W. D., 1967. Extraordinary sex ratios. Science 156: 477-488.

Hanstén, C., M. Pekkarinen \& I. Valovirta, 1997. Effect of transplantation of the gonad development of the freshwater pearl mussel, Margaritifera margaritifera (L.). Boreal Environment Research 2: 247-256.

Heard, W. H., 1998. Brooding patterns in freshwater mussels. Malacological Review (Supplement. Bivalvia I) 7: 105121.

Hebert, P. D., B. W. Muncaster \& G. L. Mackie, 1989. Ecological and genetic studies on Dreissena polymorpha (Pallas): a new mollusk in the Great Lakes. Canadian Journal of Fisheries and Aquatic Sciences 46: 1587-1591.

Hinzmann, M., M. Lopes-Lima, A. Teixeira, S. Varandas, R. Sousa, A. Lopes, E. Froufe \& J. Machado, 2013. Reproductive cycle and atrategy of Anodonta Anatina (L., 1758): notes on hermaphroditism. Journal of Experimental Zoology 319A: 378-390.

Jokela, J. \& C. M. Lively, 1995. Parasites, sex, and early reproduction in a mixed population of freshwater snails. Evolution 49: 1268-1271.

Juhel, G., S. C. Culloty, R. M. O'Riordan, J. O. O’Connor, L. de Faoite \& R. McNamara, 2003. A histological study of the gametogenic cycle of the freshwater mussel Dreissena 
polymorpha (Pallas, 1771) in Lough Derg, Ireland. Journal of Molluscan Studies 69: 365-373.

Kat, P. W., 1984. Parasitism and the Unionacea (Bivalvia). Biological Review 59: 189-207.

Kirczuk, L., J. Domagala \& M. Pilecka-Rapacz, 2015. Annual developmental cycle of gonads of European perch females (Perca fluviatilis L.) from natural sites and a canal carrying post-cooling water from the Dolna Odra Power Plant (NW Poland). Folia Biologica-Krakow 63: 85-93.

Kondo, T., 1987. Breeding seasons of seven species of unionid mussels (Bivalvia: Unionidae) in a small creek. Venus 46: 227-236.

Košel, V., 1995. The first record of Anodonta woodiana (Mollusca: Bivalvia) in Slovakia. Acta Zoologica Universitatis Comenianae 39: 3-7.

Lajtner, J. \& P. Crnčan, 2011. Distribution of the invasive bivalve Sinanodonta woodiana (Lea, 1834) in Croatia. Aquatic Invasions 6: S119-S124.

Lima, P., S. M. Monteiro, M. Sousa \& J. Machado, 2012. A histological study of oogenesis in the freshwater mussel Anodonta cygnea (Linnaeus, 1758) in Mira Lagoon, Portugal. Malacologia 55: 251-261.

Lively, C. M. \& M. F. Dybdahl, 2000. Parasite adaptation to locally common host genotypes. Nature 405: 679-681.

Lively, C. M. \& J. Jokela, 2002. Temporal and spatial distributions of parasites and sex in a freshwater snail. Evolutionary Ecology Research 4: 219-226.

Łabęcka, A.M., 2009. Cykl płciowy zawleczonych gatunków małży Sinanodonta woodiana (Lea, 1834), Corbicula fluminea (O.F. Müller, 1774) oraz Corbicula fluminalis (O.F. Müller, 1774) (Mollusca: Bivalvia) z kanału zrzutowego wód pochłodniczych Elektrowni Dolna Odra. $\mathrm{Ph}$ D Thesis, University of Szczecin, Szczecin.

MacDonald, B. A. \& R. J. Thompson, 1985. Influence of temperature and food availability on the ecological energetics of the giant scallop Placopecten magellanicus. II Reproductive output and total production. Marine Ecology Program Series 25: 295-303.

Meneghetti, F., V. Moschino \& L. Da Ros, 2004. Gametogenic cycle and variations in oocyte size of Tapes philippinarum from the Lagoon of Venice. Aquaculture 240: 473-488.

Morton, B., 1982. Some aspects of the population structure and sexual strategy of Corbicula cf. fluminalis (Bivalvia: Corbiculacea) from the Pearl River, Peoples Republic of China. Journal of Molluscan Studies 48: 1-23.

Morton, B., 1987. Comparative life history tactics and sexual strategies of the fresh and brackish water bivalve fauna of Hong Kong and southern China. American Malacological Bulletin 5: 91-99.

Motavkine, P. A. \& A. A. Varaksine, 1989. La reproduction chez les mollusques bivalves, rôle du système nerveux et règulation. Rapports Scientifiques et Techniques de l' IFREMER 10: 250.

Munjiu, O. \& I. Shubernetski, 2008. First record of Sinanodonta woodiana (Lea, 1834) (Bivalvia: Unionidae) in Moldova. Aquatic Invasions 3: 441-442.

Müller, T., M. Czarnołęski \& A. M. Łabęcka, 2012. Po co kontynuować wzrost po osiągnięciu dojrzałości płciowej - czyli czego możemy się nauczyć od małży z rodziny Unionidae. Kosmos 61: 271-280.
Müller, T., M. Czarnoleski, A. M. Labecka, A. Cichy, K. Zając \& D. Dragosz-Kluska, 2015. Factors affecting trematode infection rates in freshwater mussels. Hydrobiologia 742: 59-70.

Paunovic, M., B. Csányi, V. Simic, B. Stojanovic \& P. Cakic, 2006. Distribution of Anodonta (Sinanodonta) woodiana (Lea, 1834) in inland waters of Serbia. Aquatic Invasions 1: $154-160$.

Pekkarinen, M., 1996. Scanning electron microscopy, wholemount histology, and histochemistry of two anodontine glochidia (Bivalvia: Unionidae). Canadian Journal of Zoology 74: 1964-1973.

Pekkarinen, M. \& V. P. M. Englund, 1995a. a. Sizes of intramarsupial unionacean glochidia in Finland. Archiv für Hydrobiologie 134: 379-391.

Pekkarinen, M. \& V. P. M. Englund, 1995b. Description of unionacean glochidia in Finland, with a table aiding in their identification. Archiv für Hydrobiologie 134: 515-531.

Petró, E., 1984. The occurence and presence of Anodonta woodiana woodiana (Lea, 1834) in Hungary. Állattani Közlemények 71: 189-191.

Piechocki, A., 1969. Obserwacje biologiczne nad małżami z rodziny Unionidae w rzece Grabi. Acta Hydrobiologica 11: 57-67.

Piechocki, A., 1999. Reproductive biology of Unio pictorum (Linnaeus) and $U$. tumidus Philipsson in the Pilica River (Central Poland). Heldia 4: 53-60.

Piechocki, A., B. Wawrzyniak-Wydrowska \& B. Zdanowski, 2003. Melanoides tuberculatus (O.F. Müller, 1774) (Orthogastropoda: Thiaridae), a gastropod species new for the fauna of Poland. Folia Malacologica 11: 39-41.

Pilecka-Rapacz, M., W. Piasecki, R. Czerniawski, Ł. Sługocki, T. Krepski \& J. Domagała, 2015. The effect of warm discharge waters of a power plant on the occurrence of parasitic Metazoa in freshwater bream, Abramis brama (L.). Bulletin of European Association of Fish Pathologists 35: 94-103.

Pipe, R. K., 1987. Oogenesis in the marine mussel Mytilus edulis: an ultrastructural study. Marine Biology 95: 405-414.

Pou-Rovira, Q., R. Araujo, D. Boix, M. Clavero, C. Feo, M. Ordeix \& L. Zamo, 2009. Presence of the alien chinese pond mussel Anodonta woodiana (Lea, 1834) (Bivalvia, Unionidae) in the Iberian Peninsula. Graellsia 65: 67-70.

Rogers-Lowery, C. L. \& R. V. Dimock Jr., 2006. Encapsulation of attached ectoparasitic glochidia larvae of freshwater mussels by epithelial tissue on fins of naïve and resistant host fish. Biological Bulletin 210: 51-63.

Sárkány-Kiss, A., 1986. Anodonta woodiana (Lea, 1834) a new species in Romania (Bivalvia: Unionacea). Travaux Muséum d'Historie Naturelle „Grigore Antipa“28: 15-17.

Sayenko, E. M., T. A. Pearce \& E. K. Shea, 2005. Glochidial morphology of selected species of the genera Cristaria Schumacher, 1817 and Sinanodonta Modell, 1945 (Bivalvia: Unionidae) from Far Eastern Russia. American Malacological Bulletin 20: 11-21.

Sayenko, E. M. \& M. Soroka, 2013. Morphology of glochidia of Sinanodonta woodiana (Bivalvia: Unionidae) from Poland. The Bulletin of the Russian Far East Malacological Society 17: 214-223.

Shepardson, S. P., W. H. Heard, S. Breton \& W. R. Hoeh, 2012. Light and transmission electron microscopy of two 
spermatogenic pathways and unimorphic spermatozoa in Venustaconcha ellipsiformis (Conrad, 1836) (Bivalvia: Unionoida). Malacologia 55: 263-284.

Silayeva, A. A. \& A. A. Protasov, 2002. Zoobenthos of cooling reservoir of Khmelnitsk NPP and evaluation of water quality according to bottom invertebrates. Gidrobiologicheskii Zhurnal 38: 46-59.

Sîrbu, I., A. Sárkány-Kiss, M. Sîrbu \& A. M. Benedek, 2005. The Unionidae from Transylvania and neighbouring regions (Romania). Heldia 6: 183-192.

Skuza, L., A. M. Łabęcka \& J. Domagała, 2009. Cytogenetic and morphological charakterization of Corbicula fluminalis (O.F. Müller, 1774) (Bivalvia: Veneroida: Corbiculidae): taxonomic status assessment of a freshwater clam. Folia Biologica - Krakow 57: 177-185.

Soroka, M., 2000. Age structure and sex ratio of Anodonta woodiana (Lea, 1834) (Bivalvia: Unionidae) from Konin reservoirs (C Poland). Folia Malacologica 8: 239-244.

Soroka, M., 2005. Genetic variability among freshwater mussel Anodonta woodiana (Lea, 1834) (Bivalvia: Unionidae) populations recently introduced in Poland. Zoological Science 22: 1137-1144.

Soroka, M., 2010. Characteristics of mitochondrial DNA of unionid bivalves (Mollusca: Bivalvia: Unionidae). II. Comparison of complete sequences of maternally inherited mitochondrial genomes of Sinanodonta woodiana and Unio pictorum. Folia Malacologica 18: 189-209.

Soroka, M. \& B. Zdanowski, 2001. Morphological and genetic variability of the population of Anodonta woodiana (Lea, 1834) occurring in the Heated Konin Lakes system. Archives of Polish Fisheries 9: 239-252.

Soroka, M., M. Urbańska \& W. Andrzejewski, 2014. Chinese pond mussel Sinanodonta woodiana (Lea, 1834) (Bivalvia): origin of the Polish population and GenBank data. Journal of Limnology 73: 454-458.

Sousa, R., L. Guilhermino \& C. Antunes, 2005. Molluscan fauna in the freshwater tidal area of the River Minho estuary, NW of Iberian Peninsula. Annales de Limnologie - International. Journal of Limnology 41: 141-147.

Spyra, A., M. Strzelec, I. Lewin, M. Krodkiewska, A. Michalik-Kucharz \& M. Gara, 2012. Characteristics of Sinanodonta woodiana (Lea, 1834) populations in fish ponds (Upper Silesia, Southern Poland) in relation to environmental factors. International Review of Hydrobiology 97: 12-25.

Strzelec, M., A. Spyra \& W. Serafiński, 2006. Over thirty years of Physella acuta (Draparnaud, 1805) expansion in the
Upper Silesia and adjacent regions (Southern Poland). Malakologische Abhandlungen 24: 49-55.

Şehriban, Ç. \& H. Şereflişan, 2006. Certain reproductive characteristics of the freshwater mussel Unio terminalis delicates (Lea, 1863) in Gölbaşi Lake, Turkey. Aquaculture Research 37: 1305-1315.

Tórz, A., 2002. Kształtowanie się chemizmu wód Parku Krajobrazowego "Dolina Dolnej Odry". In Jasnowska, J. (ed.), Dolina Dolnej Odry. Monografia Parku Krajobrazowego Szczecińskie Towarzystwo Naukowe, Szczecin: 312-335.

Watters, G. T. \& S. H. O'Dee, 1999. Glochidia of the freshwater mussel Lampsilis overwintering on fish hosts. Journal of Molluscan Studies 65: 453-459.

Watters, G.T. \& S.H. O’Dee, 2000. Glochidial release as a function of water temperature: Beyond bradyticty and tachyticty. In Tankersley, R.A., D.I. Warmolts, G.T. Watters, B.J. Armitage, P.D. Johnson \& R.S. Butler (eds), Proceedings of the Conservation, Captive Care, and Propagation of Freshwater Mussels Symposium Columbus, Ohio, USA, 1998. Ohio Biological Survey, Columbus, Ohio: 135-140

Wächtler, K., M. C. Dreher-Mansur \& T. Richter, 2001. Larval Types and Early Postlarval Biology in Naiads (Unionoida). In Bauer, G. \& K. Wächtler (eds), Ecology and Evolution of the Freshwater Mussels Unionoida. Springer, Berlin-Tokyo: 93-125.

Werner, S. \& K.-O. Rothhaupt, 2007. Effects of the invasive bivalve Corbicula fluminea on settling juveniles and other benthic taxa. Journal of North American Benthological Society 26: 673-680.

Yokley Jr., P., 1972. Life history of Pleurobema cordatum (Rafinesque 1820) (Bivalvia: Unionacea). Malacologia 11: 351-364.

Zdanowski, B., 1996. Nieznana szczeżuja (Anodonta sp.) w podgrzanych jeziorach Konińskich. In Piechocki, A. (ed), XII Krajowe Seminarium Malakologiczne. Łódź, Polska, 25-27 April 1996. Wydawnictwo Uniwersytetu Łódzkiego, Łódź: 43-43.

Zieliński, K.W., 2002. Parametry morfometryczne wykorzystywane w pomiarach biomedycznych In Zieliński, K. W. \& M. Strzelelcki (eds), Komputerowa analiza obrazu biomedycznego. Wstęp do morfometrii i patologii ilościowej. Wydawnictwo Naukowe PWN, Warszawa-Łódź: $155-156$. 